\title{
The Influence of Livestock Trampling under Intensive Rotation Grazing on Soil Hydrologic Characteristics
}

\author{
S.D. WARREN, T.L. THUROW, W.H. BLACKBURN, AND N.E. GARZA
}

\begin{abstract}
Infiltration rate decreased significantly and sediment production increased significantly on a site with a silty clay surface soil devoid of vegetation following periodic trampling typical of intensive rotation grazing systems. The deleterious impact of livestock trampling generally increased as stocking rate increased. Damage was augmented when the soil was moist at the time of trampling. Thirty days of rest were insufficient to allow hydrologic recovery. Soil bulk density, aggregate stability, aggregate size distribution and surface microrelief were related to the soil hydrologic response of the trampling treatments.
\end{abstract}

Many of the world's rangelands evolved in the presence and under the influence of grazing ungulates. However, the introduction and maintenance of domestic livestock on continuously or rotationally grazed pastures has the potential for altering botanical composition and cover (Ellison 1960) and soil physical properties (Klemmedson 1956, Reed and Peterson 1961). Modification of those parameters, either singly or in concert, may accelerate the natural erosion process and result in decreased on-site productivity, increased sediment production, and increased susceptibility of downstream flooding. As stocking rates of domestic livestock are increased under continuous year-long or season-long grazing, rainfall infiltration generally decreases while runoff and sediment loss increase (Alderfer and Robinson 1947, Rauzi and Hanson 1966, Rhoades et al. 1964). Heavy continuous grazing is generally detrimental to soil hydrologic characteristics, while the effects of moderate or light continuous grazing are significantly less deleterious and frequently not significantly different from each other (Blackburn 1984, Gifford and Hawkins 1978).

Supporters of intensive rotation grazing (IRG) systems such as the short-duration grazing method propose that heavy stocking rates under some forms of rotational grazing may be advantageous

\footnotetext{
Authors are presently environmental research scientist, USA-CERL, Environmental Divison, P.O. Box 4005, Champaign, Ill. 61820; range research scientist, P.O. Box 2954, Mogadishu, Somalia; professor of watershed management, Department of Range Science. Texas A\&M University, College Station 77843; and research associate, Texas Agricultural Experiment Station, Sonora 76950. At the time of research the principal and second authors were graduate research assistants, Texas A\&M University.

This study was a cooperative project between U.S. Department of Agriculture and Texas Agricultural Experiment Station. Financial support of the Soil Conservation Service RCA Special Study and a Science/Education Grant is acknowledged.

Published with approval of the Director, Texas Agricultural Experiment Station as TA-20824

Manuscript accepted 7 July 1986.
}

to the range ecosystem (Savory 1978, 1979). Under IRG, large numbers of livestock are concentrated on small areas for short periods of time, creating a "herd effect" or intensive trampling of the soil surface. Proponents of IRG contend that this "hoof action" will enhance infiltration of rainfall into the soil and reduce erosion, even when conventional stocking rates are doubled or tripled (Goodloe 1969, Savory 1983, Savory and Parsons 1980).

Previous reviews of the impacts of grazing systems on watershed characteristics have concluded that there are no consistently significant advantages to be accrued by implementing specialized grazing systems (Blackburn 1984, Gifford and Hawkins 1976, Shiflet and Heady 1971, Van Poollen and Lacey 1979). Heavy stocking rates are almost universally detrimental to rainfall infiltration and sediment loss, regardless of the grazing system in use (Blackburn 1984; Gamougoun et al. 1984; McCalla et al. 1984a, 1984b; Pluhar 1984; Smith 1980; Thurow 1987, Weltz 1983). Unfortunately, it is often unclear if the effects are caused by livestock hooves on the soil surface or by the removal of vegetation which would otherwise protect the soil from raindrop impact, increase soil porosity through root activity, and provide an organic substrate for soil arthropod and microbe activity.

Several studies have attempted to determine the impacts of livestock trampling in the absence of concomitant removal of vegetation, and have generally concluded that trampling compacts the soil, reduces rainfall infiltration rates, and increases soil erosion. Busby and Gifford (1981), Dadkhah and Gifford (1980), and Packer (1953) used mechanical trampling devices which imitated the compacting force of a livestock hoof but did not provide a rocking or churning effect caused by a hoof when walking. Bryant et al. (1972) used live animals, but neither they nor the former researchers related the degree of trampling disturbance to that which would occur in an intensive rotation grazing system. Edmond (1958, 1963, 1964) and Witschi and Michalk (1979) used sheep to reproduce the equivalent of a single day of grazing at several stocking rates. However, the studies were conducted on fertilized, irrigated pastures, a situation which is atypical of most of the world's rangelands. Albeit ungrazed, the ameliorating presence of live plant cover was present in all of the aforementioned studies.

The objective of this study was to evaluate the effect that livestock trampling has on infiltration rates and sediment production when a bare soil is subjected to trampling intensities incurred under 
an intensive rotation grazing system, in order to test the hypothesized beneficial effects of the "herd effect" or "hoof action." The study was conducted on a bare soil to remove confounding effects due to variability in vegetative cover and botanical composition.

\section{Study Area}

Research was conducted at the Texas Agricultural Experiment Station near Sonora, Texas $\left(31^{\circ} \mathrm{N} ; 100^{\circ} \mathrm{W}\right)$. The study site had been protected from grazing and all other cultural activity for 7 years. The soil was a Kavett series (montmorillonitic, thermic, shallow Petrocalcic Calciustoll); all horizons above the rootrestricting petrocalcic horizon at $25-50 \mathrm{~cm}$ depth were of silty clay texture. The solum was characterized by a high shrink-swell capacity and a relatively high organic matter content $(>4 \%)$. Slopes were negligible $(<3 \%)$. During previous years, the site supported a moderate cover of annual forbs. However, during the spring of 1984 , the site was treated with 2,4-D. The herbicide, coupled with a severe summer drought, kept the site free from vegetation.

\section{Methods}

\section{Trampling Rates}

In order to accurately recreate the number of hoof impacts caused by a livestock herd per unit area per day, digital pedometers similar to those used by Walker et al. (1985) were placed on 5 Brangus heifers while they grazed with a livestock herd on a 32-ha pasture from a moderately stocked, 14-pasture intensive rotation grazing system at the Sonora Experiment Station. The pedometers were precalibrated and fastened to the foreleg metacarpus of each heifer with a plastic leg band. It was felt that distance measurements obtained from the pedometers might be inaccurate given the stride variability of any given animal when engaged in different activities such as traveling, foraging, or loafing (Anderson and Kothmann 1980, Walker et al. 1985). Therefore, the mean daily pedometer reading was multiplied by the number of heifers required to stock the intensive rotation system at a moderate rate and then divided by the area of the pasture. The resulting value was used to determine the necessary pedometer reading when recreating hoof impacts per unit area at the study site.

Four rates of trampling intensity were imposed on small paddocks $\left(110 \mathrm{~m}^{2}\right)$ in a split-plot design at the study area. They included moderate (1x) (8.1 ha/AU/yr), double (2x)(4.1 ha/ $\mathrm{AU} / \mathrm{yr})$, triple (3x)(2.7 ha/ AU/yr), and no trampling (Ex). Each treatment was replicated 3 times. Treatments were repeated 5 times at 30-day intervals, commencing on 20 May and concluding on 20 September. At each sample date, prior to trampling, half of each paddock was wetted by sprinkling with approximately $10 \mathrm{~mm}$ of water in order to facilitate a comparison of the effect of trampling under both moist and dry conditions. Four heifers averaging 240 $\mathrm{kg}$ were used to create hoof impacts on the small paddocks. The heifers were forced to walk within the paddocks until the sum of their pedometer readings equaled the value that would be recorded by an entire herd at a given stocking rate on an equivalent area during a 4-day grazing period.

\section{Infiltration and Sediment}

Data on infiltration rate and sediment production were taken from each paddock at the first, third, and last trampling date. A mobile, drip-type rainfall simulator (Blackburn et al. 1974) was used to determine infiltration rate and sediment production from $0.5-\mathrm{m}^{2}$ plots before and after trampling at each sample date. Two replications of both dry-and moist-trampled plots were run in each paddock at each sample date. Simulated rainfall was applied at a rate of $203 \mathrm{~mm} \mathrm{~h}^{-1}$ for 45 minutes. The simulated raindrops were $2.5 \mathrm{~mm}$ in diameter. Drops falling $2.1 \mathrm{~m}$ reach $5.25 \mathrm{~m} / \mathrm{sec}$ or $71 \%$ of the terminal velocity achieved by raindrops in an unlimited fall (Laws 1941). This application rate simulated a storm with a return period of 150 years and was necessary to insure runoff from all plots. Runoff from each plot was pumped regularly into tared holding bottles and weighed at 5-minute intervals throughout the simulated rainfall event. Weights were converted volume measurements, and infiltration rates $\left(\mathrm{mm} \mathrm{h}^{-1}\right)$ were determined by calculating the difference between applied rainfall and runoff. At the termination of each simulated rainfall event, the runoff collected from each plot was thoroughly mixed and a 1-liter subsample was taken. The subsample was filtered through a tared \#1 Whatman filter. The sediment retained by the filter was ovendried, weighed, and converted to sediment yield $\left(\mathrm{kg} \mathrm{ha}^{-1}\right)$ based on total runoff and plot size.

\section{Soil Characteristics}

Immediately prior to each simulated rainfall event, soil bulk

Table 1. Mean infiltration rate after 45 minutes and sediment production in relation to trampling intensity, soil water content at the time of trampling, and pre- or post-trample condition on the Edwards Plateau, Texas.'

\begin{tabular}{|c|c|c|c|c|c|c|}
\hline \multirow[b]{3}{*}{$\begin{array}{l}\text { Trampling } \\
\text { intensity }\end{array}$} & \multicolumn{6}{|c|}{ Infiltration Rate $\left(\mathrm{mm} \mathrm{h}^{-1}\right)$} \\
\hline & \multicolumn{3}{|c|}{ Trampled dry } & \multicolumn{3}{|c|}{ Trampled moist } \\
\hline & $\begin{array}{c}\text { Before } \\
\text { trampling }\end{array}$ & $\begin{array}{c}\text { After } \\
\text { trampling } \\
\end{array}$ & Mean & $\begin{array}{c}\text { Before } \\
\text { trampling } \\
\end{array}$ & $\begin{array}{c}\text { After } \\
\text { trampling }\end{array}$ & Mean \\
\hline $\begin{array}{l}0 \\
1 X \\
2 X \\
3 X \\
\text { Mean } \\
\text { Overall Mean } \\
\end{array}$ & $\begin{array}{l}166 \mathrm{a}(\mathrm{x}) \\
147 \mathrm{~b}(\mathrm{x}) \\
137 \mathrm{~b}(\mathrm{x}) \\
134 \mathrm{~b}(\mathrm{x}) \\
146 \quad(\mathrm{x})\end{array}$ & $\begin{array}{l}166 a(x) \\
132 b(x) \\
106 c(y) \\
101 c(y z) \\
126(y z)\end{array}$ & $\begin{array}{l}166 \mathrm{a} \\
140 \mathrm{~b} \\
121 \mathrm{c} \\
117 \mathrm{c} \\
136(\mathrm{x}) \\
\end{array}$ & $\begin{array}{l}160 \mathrm{a}(\mathrm{x}) \\
133 \mathrm{~b}(\mathrm{x}) \\
115 \mathrm{bc}(\mathrm{y}) \\
109 \mathrm{c}(\mathrm{y}) \\
129(\mathrm{y})\end{array}$ & $\begin{array}{c}160 \mathrm{a}(\mathrm{x}) \\
130 \mathrm{~b}(\mathrm{x}) \\
83 \mathrm{c}(\mathrm{z}) \\
82 \mathrm{c}(\mathrm{z}) \\
114 \quad(\mathrm{z})\end{array}$ & $\begin{array}{c}160 \mathrm{a} \\
133 \mathrm{~b} \\
99 \mathrm{c} \\
96 \mathrm{c} \\
122(\mathrm{y}) \\
\end{array}$ \\
\hline \multirow{2}{*}{ Overall Mean } & \multicolumn{6}{|c|}{ Sediment Production $\left(\mathrm{kg} \mathrm{ha}^{-1}\right)$} \\
\hline & \multicolumn{3}{|c|}{ Trampled dry } & \multicolumn{3}{|c|}{ Trampled moist } \\
\hline $\begin{array}{l}\text { Trampling } \\
\text { intensity }\end{array}$ & $\begin{array}{c}\begin{array}{c}\text { Before } \\
\text { trampling }\end{array} \\
\end{array}$ & $\begin{array}{c}\text { After } \\
\text { trampling }\end{array}$ & Mean & $\begin{array}{c}\text { Before } \\
\text { trampling } \\
\end{array}$ & $\begin{array}{c}\text { After } \\
\text { trampling } \\
\end{array}$ & Mean \\
\hline $\begin{array}{l}0 \\
1 X \\
2 X \\
3 X \\
\text { Mean } \\
\text { Overall Mean }\end{array}$ & $\begin{array}{l}976 a(x) \\
1829 b(x) \\
2272 b(x) \\
2211 b(x) \\
1804(x)\end{array}$ & $\begin{array}{l}976 a(x) \\
3824 b(y) \\
4605 b(y) \\
7078 c(y) \\
4122 \quad(z)\end{array}$ & $\begin{array}{r}976 \mathrm{a} \\
2827 \mathrm{~b} \\
3438 \mathrm{~b} \\
4788 \mathrm{c} \\
3078 \text { (x) }\end{array}$ & $\begin{array}{l}2007 \mathrm{a}(\mathrm{x}) \\
2998 \mathrm{ab}(\mathrm{xy}) \\
3542 \mathrm{~b}(\mathrm{xy}) \\
4057 \mathrm{~b}(\mathrm{x}) \\
3141 \quad(\mathrm{y})\end{array}$ & $\begin{array}{l}2007 a(x) \\
2752 a(x y) \\
5048 b \text { (y) } \\
7465 c \quad(y) \\
4308 \quad(z)\end{array}$ & $\begin{array}{l}2007 a \\
2875 a \\
4274 b \\
5861 c \\
3811(y)\end{array}$ \\
\hline
\end{tabular}

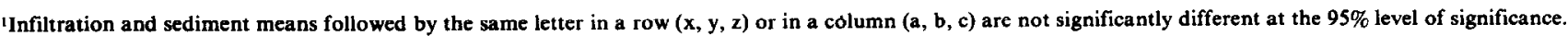


density and soil water content at a depth of 0-50 $\mathrm{mm}$ were determined adjacent to the runoff plot by the sand-funnel method (Blake 1965) and gravimetric method (Roundy et al. 1983), respectively. A composite soil sample of the surface $25 \mathrm{~mm}$ was collected from the area adjacent to each plot in order to determine aggregate size distribution by the dry sieving method (Kemper and Chepil 1965). The percentage weight of aggregates in size classes of $4.75-2.0,2.0-1.0,1.0-0.5,0.5-0.21$, and $<.21 \mathrm{~mm}$ from an initial $100 \mathrm{~g}$ sample were incorporated into the mean-weight diameter equation (Youker and McGuinness 1956) to produce a single value which reflects relative aggregate size distribution. The larger the mean weight diameter value, the greater the proportion of larger aggregates.

Following each simulated rainfall event, soil surface microrelief within each plot was measured with a 10-pin relief meter similar to the one described by Kincaid and Williams (1966). A soil surface sample (0-50 mm) was taken from within each plot, air dried, ground through a $2-\mathrm{mm}$ sieve, and analyzed for aggregate stability by the wet sieve method (Kemper 1965).

Prior to trampling at each date, two $1.0-\mathrm{kg}$ soil samples were taken from both the dry and moist side of each paddock and soil moisture was determined gravimetrically (Roundy et al. 1983).

\section{Analysis}

Data were evaluated based on a split-plot design. In order to remove date-to-date variability and variability due to soil water content, while allowing for cumulative trampling effects, infiltration rates and sediment production from non-trampled paddocks at each date were adjusted to the overmean value for all dry, non-trampled paddocks. Infiltration rate and sediment production values for trampled paddocks were adjusted to the same degree as values for non-trampled paddocks at the respective dates. This provided a much clearer representation of treatment differences. Following adjustments, an analysis of variance was conducted to determine differences between moist and dry plots, trampling intensities, and pre- and post-trample conditions in terms of infiltration rate and sediment production. If differences were present, Duncan's multiple comparison test was used to separate the means (Steel and Torrie 1980).

\section{Results and Discussion}

Mean infiltration rates were determined after a period of 5,10 , $15,20,25,30,35,40$, and 45 minutes. Because of similarity of the data for the different time periods, only mean infiltration rate after 45 minutes will be discussed. Across all trampling intensities, mean infiltration rate was significantly higher and sediment production was significantly lower from plots which were trampled dry than from plots which were trampled moist (Table 1). This coincides with previous research which indicates that moist soils are often much more susceptible to compaction than dry soils (Edmond 1962, Lull 1959), especially at the very surface where a thin, impermeable layer may form (Beckmann and Smith 1974). Average soil water content in the surface $20 \mathrm{~mm}$ at the time of trampling in this study was 5.1 and $25.2 \%$ for the dry and moist plots, respectively. If the amount of water applied to the wetted plots had been increased, even greater disparity may have developed between dry and moist plots.

Infiltration rate was consistently higher and sediment production lower but not necessarily significantly higher or lower, before trampling than after regardless of soil moisture status at the time of trampling (Figs. 1 and 2). The difference between pre- and posttrample infiltration rate and sediment production was generally significant at the higher stocking rates $(2 x$ and $3 x$ ) but not under a moderate trampling regime (1x) (Table 1 ). This is consistent with Pluhar (1984), Warren et al. (1986a), and Weltz (1983), who demonstrated that infiltration rates were lower and sediment production was higher immediately following short-term high intensity grazing periods inherent in heavily stocked IRG systems. Pluhar
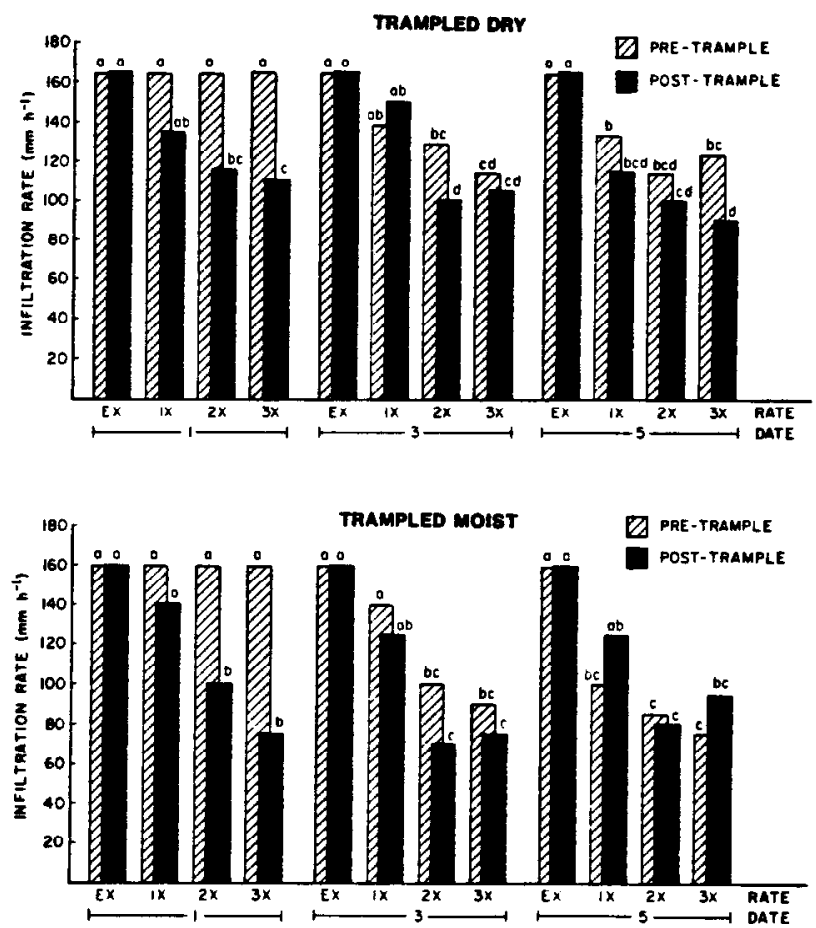

Fig. 1. Mean infiltration rate after 45 minutes in relation to soil moisture at the time of trampling, pre- or post-trample condition, trampling rate, and sample date on the Edwards Plateau, Texas. (Means with the same letter within the same date and soil moisture status are not significantly different at the $95 \%$ level).
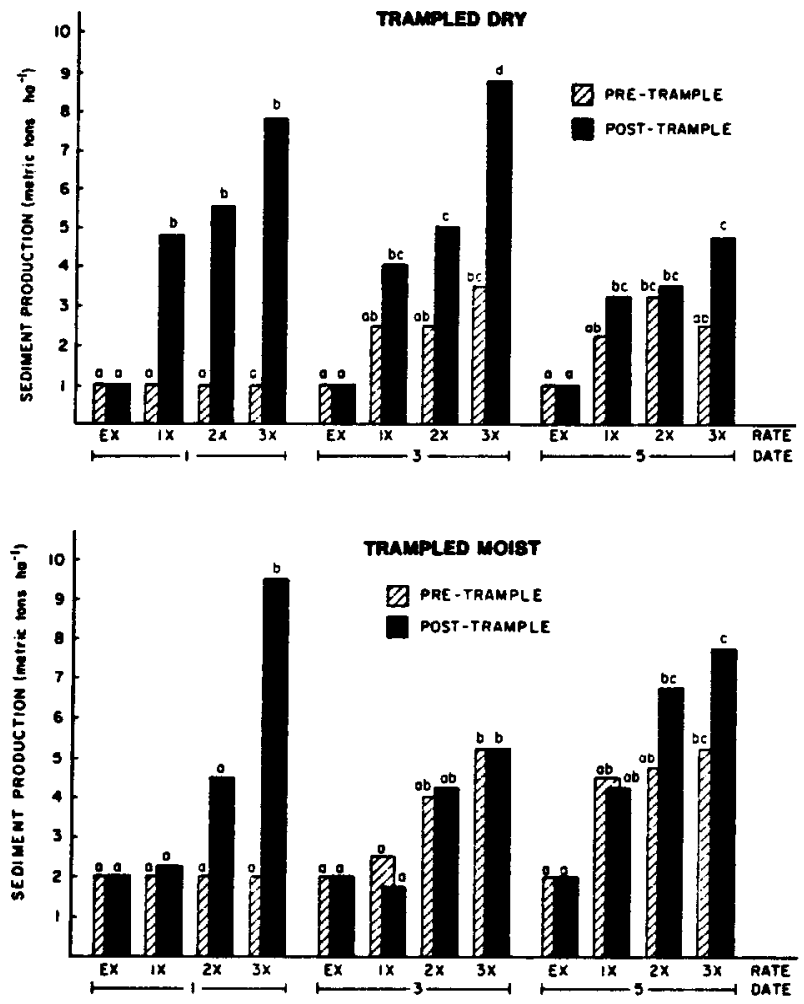

Fig. 2. Mean sediment production in relation to soil moisture at the time of trampling, pre- or post-trample condition trampling rate, and sample date on the Edwards Plateau, Texas. (Means with the same letter within the same sample date and soil moisture status are not significantly different at the $95 \%$ level). 
(1984) and Weltz (1983) attributed the majority of the effect to the removal of standing vegetation. However, where vegetation is sparse, as in many semi-arid and arid regions, or where it is altogether absent as in this study, the effect of trampling must be attributed to changes in soil physical properties (Warren et al. 1986b).

Under both moist and dry soil conditions, trampling at a $1 \mathrm{x}$ stocking rate resulted in a significant decline in infiltration rate when compared to the untrampled paddocks (Table 1). A $2 x$ or $3 x$ stocking rate caused an additional significant decline. However, the $2 \mathrm{x}$ and $3 \mathrm{x}$ stocking rates were not significantly different from each other. Mean sediment production responded in a similar but inverse fashion as stocking rate increased (Table 1). However, unlike infiltration rate, the difference in sediment production between the $2 \mathrm{x}$ and $3 \mathrm{x}$ stocking rates was significant.

The reduction in hydrologic condition incurred by trampling at the high stocking rates under IRG did not appear to be cumulative. The decline in infiltration rate and increase in sediment production was apparently maximized by the third trampling date (Fig. 1 and 2). Some recovery of the soil appeared to occur during the 30-day rest periods as evidenced by higher pre-trample infiltration rates and lower pre-trample sediment production than the previous post-trample condition, even at the last sample date. Under the dry conditions encountered in this study, recovery was minimal and under no circumstances did infiltration rate or sediment production on the more heavily trampled paddocks recover to a level comparable to the trampling exclosures. The time required for significant recovery of soil hydrologic condition was not addressed by the experimental design and remains a viable research opportunity. Previous research on optimum rest periods for rotational grazing has dealt primarily with forage and animal response (Denny and Barnes 1977, Morley 1968, Noy-Meir 1976). Recovery of infiltration rates or sediment production following trampling has seldom been addressed and is easily confounded with recovery of vegetative cover. Recovery of the soil may be especially important in arid, semiarid, and disturbed or overgrazed temperate areas where vegetation is sparse.

Rate of trampling intensity, as well as many soil variables was significantly correlated with infiltration rate and sediment production (Table 2). Soil bulk density was the best predictor of infiltration rate and sediment production, regardless of soil moisture

\section{Table 2. Simple correlation coefficients of variables correlated with mean infiltration rate after $\mathbf{4 5}$ minutes and sediment production on soil trampled dry and moist on the Edwards Plateau, Texas. ${ }^{1}$}

\begin{tabular}{|c|c|c|c|c|}
\hline \multirow[b]{2}{*}{ Variable } & \multicolumn{2}{|c|}{ Infiltration Rate } & \multicolumn{2}{|c|}{ Sediment Production } \\
\hline & $\begin{array}{c}\text { Trampled } \\
\text { dry }\end{array}$ & $\begin{array}{c}\text { Trampled } \\
\text { moist }\end{array}$ & $\begin{array}{l}\text { Trampled } \\
\text { dry }\end{array}$ & $\begin{array}{c}\text { Trampled } \\
\text { moist }\end{array}$ \\
\hline Trample rate & -.45 & -.40 & .42 & .40 \\
\hline Soil bulk density & -.55 & -.64 & .65 & .64 \\
\hline Soil surface microrelief & .28 & .41 & -.30 & -.34 \\
\hline Soil aggregate stability & .23 & .39 & $-.14 \mathrm{NS}$ & -.53 \\
\hline Aggregate size distribution & $.09 \mathrm{NS}$ & -.36 & -.21 & -.30 \\
\hline
\end{tabular}

'Correlation coefficients followed by NS are not significant at the $95 \%$ level of significance.

condition at the time of trampling. It is well established that heavy stocking rates under continuous grazing lead to increased bulk density and, in turn, to reduced infiltration rates and increased sediment production (Alderfer and Robinson 1947, Knoll and Hopkins 1959, Rauzi and Hanson 1966). These results indicate that a similar response can be expected under IRG systems.

Soil surface microrelief was also significantly correlated to infiltration rate and sediment production (Table 2), although unrelated to trampling rate (Warren et al. 1986b). Natural undulations and depressions on the soil surface may slow overland flow allowing more water to infiltrate and causing deposition of suspended soil particles.
Size and stability of soil aggregates are generally closely related to soil hydrologic response (Free et al. 1940; Wood and Blackburn 1981a, 1981b). Interspaces between large aggregates increase the macroporosity of the soil which, in turn, enhances infiltration rate. As infiltration rate increases, less runoff is available to transport sediment. In addition, large aggregates are less likely to be transported by surface runoff water. Unstable aggregates, which are easily disrupted by raindrop impact, may clog soil pores causing a reduction in infiltration and an increase in sediment production. Both aggregate size distribution and aggregate stability were significantly correlated to soil hydrologic response in this study (Table 2). However, contrary to the predicted response, aggregate size distribution was negatively correlated to infiltration rate and positively correlated to sediment production on soil which was trampled while moist. This was caused by the formation of large, comparatively impermeable clods when the soil was compacted while moist (Warren et al. 1986b).

\section{Literature Cited}

Alderfer, R.B., and R.R. Robinson. 1947. Runoff from pastures in relation to grazing intensity and soil compaction. J. Amer. Soc. Agron. 39:948-958

Anderson, D.M., and M.M. Kothmann. 1980. Relationship of distance traveled with diet and weather for Hereford heifers. J. Range Manage. 33:217-220.

Beckmann, G.G., and K.J. Smith. 1974. Micromorphological changes in surface soils following wetting, drying and trampling, p. 832-845. In: G.K. Rutherford (ed), Soil Microscopy: Proceedings of the Fourth Internat., Working-meeting on Soil Micromorphology. The Limestone Press, Kingston, Ontario.

Blackburn, W.H. 1984. Impacts of grazing intensity and specialized grazing systems on watershed characteristics and responses, p. 927-983. In: Developing Strategies for Rangeland Management. Nat. Res. Council/ Nat. Acad. Sci.. Westview Press, Boulder, Colo.

Blackburn, W.H., R.O. Meeuwig, and C.M. Skau. 1974. A mobile infiltrometer for use on rangeland. J. Range Manage. 27:322-323.

Blake, G.R. 1965. Bulk density, p. 374-390. In: C.A. Black (ed), Methods of Soil Analysis, Part I. Amer. Soc. Agron. Madison, Wis.

Bryant, H.T., R.E. Blaser, and J.R. Peterson. 1972. Effect of trampling by cattle on bluegrass yield and soil compaction of a Meadowville loam. Agron. J. 64:331-334.

Busby, F.E., and G.F. Gifford. 1981. Effects of livestock grazing on infiltration and erosion rates measured on chained and unchained pinyonjuniper sites in southeastern Utah. J. Range Manage. 34:400-405.

Dadkhah, M., and G.F. Gifford. 1980. Influence of vegetation, rock cover and trampling on infiltration rates and sediment production. Water Resources Bull. 16:979-986.

Denny, R.P., and D.L. Barnes. 1977. Trials of multi-paddock grazing systems on veld. 3 . A comparison of 6 grazing procedures at 2 stocking rates. Rhodesia J. Agr. Res. 15:129-142.

Edmond, D.B. 1958. The influence of treading on pasture: A preliminary study. N.Z. J. Agr. Res. 1:319-329.

Edmond, D.B. 1962. Effects of treading pasture in summer under different soil moisture levels. N.Z. J. Agr. Res. 5:389-395.

Edmond, D.B. 1963. Effects of treading perennial ryegrass (Lolium perenne L.) and white clover (Trifolium repens $\mathrm{L}$.) pastures in winter and summer at two soil moisture levels. N.Z. J. Agr. Res. 6:265-276.

Edmond, D.B. 1964. Some effects of sheep treading on the growth of 10 pasture species. N.Z. J. Agr. Res. 7:1-16.

Ellison, L. 1960. Influence of grazing on plant succession of rangelands. Bot. Rev. 26:1-78.

Free, G.R., G.M. Browning, and G.W. Musgrave. 1940. Relative infiltration and related physical characteristics of certain soils. USDA Tech. Bull. 729.

Gamougoun, N.D., R.P. Smith, M.K. Wood, and R.D. Pieper. 1984. Soil, vegetation, and hydrologic responses to grazing management at Fort Stanton, New Mexico. J. Range Manage. 37:538-541.

Gifford, G.F., and R.H. Hawkins. 1976. Grazing systems and watershed management: $A$ look at the record. J. Soil and Water Conserv. 31:281-283.

Gifford, G.F., and R.H. Hawkins. 1978. Hydrologic impact of grazing on infiltration: A critical review. Water Resources Res. 14:305-313.

Goodloe, S. 1969. Short-duration grazing in Rhodesia. J. Range Manage. 22:369-373. 
Kemper, W.D. 1965. Aggregate stability, p. 51 1-519. In: C.A. Black (ed), Methods of Soil Analysis, Part 1. Amer. Soc. Agron., Madison, Wis.

Kemper, W.D., and W.S. Chepil. 1965. Size distribution of aggregates, p. 499-510. In: C.A. Black (ed), Methods of Soil Analysis, Part 1. Amer. Soc. Agron. Madison, Wis.

Kincaid, D.R., and G. Williams. 1966. Rainfall effects on soil surface characteristics following range improvement treatments. J. Range Manage. 19:346-351.

Klemmedson, J.O. 1956. Interrelations of vegetation, soils and range conditions induced by grazing. J. Range Manage. 9:134-138.

Knoll, G., and H.H. Hopkins. 1959. The effects of grazing and trampling upon certain soil properties. Trans. Kansas Acad. Sci. 62:221-231.

Luws, J.O. 1941. Measurements of the fall-velocity of water-drops and raindrops. Trans. Amer. Geophysical Union 22:709-721.

Lull, H.W. 1959. Soil compaction on forest and range lands. USDA Misc. Pub. 768.

McCalla, G.R., W.H. Blackburn, and L.B. Merrill. 1984a. Effects of livestock grazing on infiltration rates, Edwards Plateau of Texas. J. Range Manage. 37:265-269.

McCalla, G.R., W.H. Blackburn, and L.B. Merrill. 1984b. Effects of livestock grazing on sediment production, Edwards Plateau of Texas. J. Range Manage. 37:291-294.

Morley, F.H.W. 1968. Pasture growth curves and grazing management. Aust. J. Exp. Agr. and Anim. Husb. 8:40-45.

Noy-Meir, I. 1976. Rotational grazing in a continuously growing pasture: A simple model. Agr. Systems 1:87-112.

Packer, P.E. 1953. Effects of trampling disturbance on watershed condition, runoff, and erosion. J. Forest. 51:28-31.

Pluhar, J.J. 1984. Hydrologic impacts of selected grazing systems on the Texas Rolling Plains. M.S. Thesis, Texas A\&M Univ., College Station.

Rauzi, F. and C.L. Hanson. 1966. Water intake and runoff as affected by intensity of grazing. J. Range Manage. 19:351-356.

Reed, M.J., and R.A. Peterson. 1961. Vegetation, soil, and cattle responses to grazing on Northern Great Plains range. USDA Tech. Bull. 1252.

Rhoades, E.D., L.F. Locke, H.M. Taylor, and E.H. Mcllvain. 1964. Water intake on a sandy range as affected by 20 years of differential cattle stocking rates. J. Range Manage. 17:185-190.

Roundy, B.A., J.A. Young, G.J. Cluff, and R.A. Evans. 1983. Measurement of soil water on rangelands. USDA Agr. Res. Service, Agr. Res. Results, Western Ser. 31.

Savory, A. 1978. A holistic approach to ranch management using short duration grazing, p. 555-557. In: Proceedings of the First Internat. Range. Cong., Soc. Range Manage., Denver, Colo.
Savory, A. 1979. Range management principles underlying short duration grazing, p. 375-379. In: Beef Cattle Science Handbook. Agriservices Foundation, Clovis, CA.

Savory A. 1983. The Savory grazing method or holistic resource management. Rangelands 5:155-159.

Savory, A., and S.D. Parsons. 1980. The Savory grazing method. Rangelands 2:234-237.

Shiflet, T.N., and H.F. Heady. 1971. Specialized grazing systems: Their place in range management. USDA Soil Conserv. Service TP- 152.

Smith, R.P. 1980. The influence of different grazing practices on infiltration rates and sediment production at Fort Stanton, New Mexico. M.S. Thesis, New Mexico State Univ., Las Cruces, NM.

Steel, R.G.D., and J.H. Torrie. 1980. Principles and procedures of statistics. McGraw-Hill Book Co,, New York.

Thurow, T.L. 1987. Hydrologic characteristics of vegetation types as affected by livest ock grazing systems, Edwards Plateau, Texas J. Range Manage. 40:( In press).

Van Poollen, H.W., and J.R. Lacey. 1979. Herbage response to grazing systems and stocking intensities. J. Range Manage. 32:250-253.

Walker, J.W., R.K. Heitschmidt, and S.L. Dowhower. 1985. Evaluation of pedometers for measuring distance traveled by cattle on two grazing systems. J. Range Manage. 38:90-93.

Warren, S.D., W.H. Blackburn, and C.A. Taylor, Jr. 1986a. Effects of season and stage of rotation cycle on hydrologic condition of rangeland under intensive rotation grazing. J. Range Manage. 39:486-491.

Warren, S.D., M.B. Neville, W.H. Blackbum, and N.E. Garza. 1986b. Soil response to trampling under intensive rotation grazing. Soil Sci. Soc. Amer. J. (50): (In press).

Weltz, M. 1983. The influence of short duration and continuous grazing on infiltration rate and sediment yield in southcentral New Mexico. M.S Thesis, New Mexico State Univ., Las Cruces, NM.

Witschi, P.A., and D.L. Michalk. 1979. The effect of sheep treading and grazing on pasture and soil characteristics of irrigated annual pastures. Aust. J. Agr. Res. 30:741-750.

Wood, M.K., and W.H. Blackburn. 1981a. Grazing systems: Their influence on infiltration rates in the Rolling Plains of Texas. J. Range Manage. 34:331-335.

Wood, M.K., and W.H. Blackburn. 1981b. Sediment production as influenced by livestock grazing in the Texas Rolling Plains. J. Range Manage. 34:228-231.

Youker, R.E., and J.L. McGuinness. 1956. A short method of obtaining mean weight-diameter values of aggregate analyses of soils. Soil Sci. 83:291-294.

\section{Graduate Student Papers}

Papers accepted for presentation by graduate students or recent graduates reporting graduate study research are eligible for a cash award contest to be held for the first time by SRM at the Idaho meeting. Papers will be evaluated as they are presented in their respective sessions by appointed judges, and winners selected according to cumulative scores by the judges.

Students interested in participating or inquiring about the contest should write: Pete W. Jacoby, Jr., Texas Agricultural Experiment Station, P.O. Box 1658, Vernon, TX 76384. 